\title{
THE USE OF CLOZE TEST TO TEST READING COMPREHENSION OF NON-ENGLISH DEPARTMENT STUDENTS
}

\author{
Sri Sukarni \\ English Lecturer, FBMB, Universitas Pendidikan Mandalika, Indonesia \\ Corresponding Author Email: srisukarni@ undikma.ac.id
}

\begin{abstract}
A B S T R A C T S
This research aimed to describe the result of the non-English department students' reading comprehension tested by using cloze test and the effect of using cloze test on non-English department students' achievement on reading comprehension. This research is classified into pre-experimental research that used one group pre-test and post-test design. The population of this research is the non-English department students in the academic Year 2020/2021 with a total number of 107 students. The researcher used non-probability sampling type purposive sampling technique and there were 44 students taken as samples. The test is the instrument in this research. Data are taken from the result of pre-test and post-test then analyzed by using statistical technique. The analysis is used to find the significant difference in the students' reading comprehension ability before and after the use of cloze test. In this research, the researcher used paired sample t-test through SPSS 17.0 to analyze the data. Based on data analysis, the mean score of the pre-test was 46.86 categorized as poor whereas the mean score of the post-test was 65.61 categorized as average to good. The mean score of the pre-test 46.86 smaller than 65.61 mean scores of the post-test. It meant that there was a difference mean score of students' reading comprehension between the pre-test and post-test. This finding showed there was a different score before and after giving treatment. The result of paired samples t-test analysis showed the significance value Sig. (2-tailed) < alpha $(0.000<$ $0.05)$. Therefore, the alternative hypotheses which stated that there is an effect of using cloze test on improving non-English department students' reading comprehension is accepted. It is concluded that there was an effect of cloze test on improving non-English department students' reading comprehension.
\end{abstract}

\begin{tabular}{l}
\hline A R T I C L E I N F O \\
\hline Article History: \\
Received: May, 2021
\end{tabular}

Revised: May, 2021

Published: June, 2021

Keywords:

Cloze test,

Reading Comprehension,

How to cite: Sukarni, S. (2021). The Use of Cloze Test To Test Reading Comprehension of Non-English Department Students. Jo-ELT (Journal of English Language Teaching) Fakultas Pendidikan Bahasa \& Seni Prodi Pendidikan Bahasa Inggris IKIP, 8(1), 74-82. doi:https://doi.org/10.33394/jo-elt.v8i1.3788

\section{INTRODUCTION}

In line with the status of the English language in Indonesia as the first foreign language, reading gets more proportion in the teaching and learning process. In the context of the goal of teaching English at a tertiary level of education especially for non-English department students is to improve their ability to use English for academic and professional purposes, especially for reading textbooks in their academic work. This implies that in the English language instruction, reading skill has been given the greatest prominence for helping students to learn effectively in their field of study. Eskey (2005) pointed out, many students of English as a foreign language (EFL), rarely speak English in their everyday life but may 
need to read in order to access information recorded exclusively in the language. Therefore, assessment towards students' reading comprehension ability aims to monitor students' difficulties, students' achievement, and students' proficiency on English reading texts.

However, there are some problems that English teachers find in testing reading comprehension. One of the problems is how to select a suitable testing technique according to skill and aspect of language to be measured. The testing technique will be used by the teachers should eliminate the opportunity of students to chat, guess, or predict the answers to questions. Based on the problems, it can be inferred that it is important to prepare a kind of tool for measuring students' mastery on reading comprehension and understanding the purpose of reading comprehension. It also implies that when English teachers design a test for reading comprehension, they have to decide what they want to test and find a means of testing it.

According to RAND Reading Study Group (2002), defined comprehension is the process of eliciting and making through interaction and involvement with written language. McNamara and Magliano (2009) emphasized that this process is a task of both reader and text factors that happen within a larger social context. Duke (2003) stated that comprehension is a process in which readers make meaning by interacting with the text through the combination of prior knowledge and previous experience, information in the text, and the views of readers related to the text.

Kintsch (1988) stated that reading comprehension is defined as the process of creating meaning from text. The purpose is to get an understanding of the text rather than to acquire meaning from individual words or sentences. The outcome of reading comprehension is the mental representation of a text meaning that is combined with the reader's previous knowledge. According to Olson and Diller (1982), what is meant by reading comprehension is a term used to identify skills needed to understand and apply information contained in written material. In this case, the students should be able to gain the information from reading text. Related to reading comprehension, Richard and Schmidt (2002) stated that reading is an activity of perceiving a written text in order to understand its contents. This can be done silently (silent reading). The understanding of the contents of reading is called reading comprehension. Based on the definitions it can be inferred that reading comprehension is a process of constructing meaning from a written text that involves the interaction of the reader's prior knowledge with the new given information.

Some of the testing techniques that can assess reading skill according to Brown (2004) are written answer, short answer, summary, ordering the test, multiple-choice items, matching, gap-filling test, cloze test, and C test. Concerning the cloze test, Harmer (2002) stated that cloze, in its purest form, is the deletion of every n-th word in a text (somewhere between every fifth and tenth word). Brown (2000) said that close procedure is one of the tests that can help the teachers to teach reading comprehension. Through the test, the students are able to know the information in a text. Heaton (1998) said the most common purpose of the cloze test is to measure reading comprehension. He said so because it has long been argued that cloze measures textual knowledge: i.e an awareness of cohesion in a text, involving the interdependence of phrase, sentence, and paragraph within cloze test. He also stated that cloze test can be applied to the testing of reading comprehension at both levels elementary and more advanced levels. Moreover, cloze test is intended to such a degree to demonstrate if the testee is acquainted with the language and context of the text in a way that maintains the intended meaning of the author (Oller \& Jonz, 1994). Likewise, cloze test assesses the testee's ability to benefit from the text contextual clues to obtain meaning.

Many researchers have conducted some researches about cloze test and its implication toward reading comprehension. Ema (2019) designed a test for reading comprehension. The result of her research showed that students got cloze test score higher than multiple-choice 
score because most of them said that multiple-choice test is difficult than cloze test. Febriyanti (2017) did research and she found that there was a correlation between reading comprehension and students' ability in answering cloze test. Wahdaniah, et all (2013) proved that students' performances in reading comprehension is average to good, or in other words, the use of cloze test significantly improved reading comprehension. John Oller (2006) believed that the sort of competence related to second language proficiency measured by cloze test. Lu (2006) stated that cloze test used by teachers and for tests can be improved to facilitate students' reading competence.

In this research, the researcher wants to describe the result of the non-English department students' reading comprehension tested by using cloze test and the effect of using cloze test on non-English department students' achievement on reading comprehension.

\section{RESEARCH METHOD \\ Research Design}

This research is classified into pre-experimental research that used one group pre-test and post-test design. One group pre-test and post-test design is a single group measured not only after being exposed to a treatment of some sort but also before a treatment. A pre-test provides a measure on some attribute or characteristic that is assessed in an experiment before a group gets a treatment, while a post-test measure on some characteristics that is assessed for participants in an experiment after a treatment. Creswell (2014) stated that an experimental design is used in which attitudes are assessed both before and after experimental treatment.

The procedures of pre-experimental research that use one group pre-test and post-test design in this research can be described: 1) administering pre-test which purpose to measure non-English department students' reading comprehension ability before applying treatment; 2) applying experimental treatment reading comprehension by using cloze test; 3) administering post-test which purpose of measuring non-English department students reading comprehension ability after applying treatment. Based on the purpose of this research, the effect of cloze test was known after finding out the significant difference between students' achievement before using cloze test and those students who are tested after using cloze test by comparing pre-test and post-test score.

\section{Population and Sample}

This research is conducted at the non-English department of Mandalika University of Education. The population of this research is the non-English department students in the academic Year 2020/2021 with a total number of 107 students, the researcher took a portion of the population which is known as a sample. The researcher used a non-probability sampling type purposive sampling technique. As the process of sampling, the researcher finally chose some students in every non-English department by considering the factor that in the experimental stage, the samples have the average ability in English especially reading comprehension. In other words, the researcher took the typical sample. It was intended to reduce the extraneous variable that may appear since the design is pre-experimental research without using a control group.

Determination of the number of samples in this research is based on Issac and Michel (1981) formula. The formula in figure 1. 


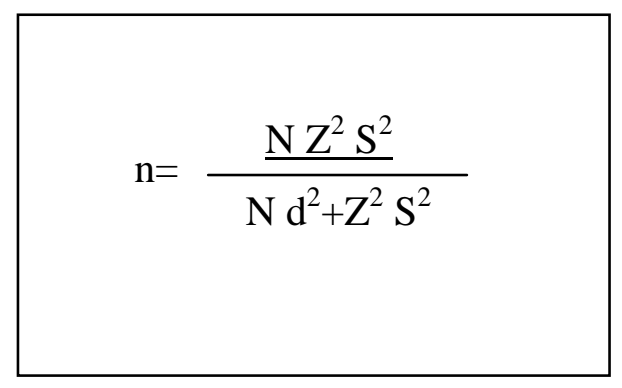

Figure 1. The Formula of Determination of the Number of Samples

Note:

$\mathrm{n}=$ sample size

$\mathrm{N}=$ population

$\mathrm{Z}=$ significant level

$\mathrm{S}=$ samples variation

$\mathrm{d}=$ deviation degree

Based on the calculation result of the formula, the researcher took 44 non-English department students as samples in this research.

\section{Instruments}

The research instrument was a test of testing techniques for reading comprehension. In collecting data, measurement is administered twice. First, the pre-test was intended to measure the students' ability before giving treatment. Second, the post-test was intended to measure students' ability after giving treatment. The aim of administering the pre-test is to get initial information on the groups before the experiment is conducted. The purpose of administering the post-test was to observe and to measure any changes in students' reading comprehension ability after being tested by cloze test.

In administering the pre-test the researcher took multiple-choice reading passages while for the post-test cloze test reading comprehension passages are applied. Those reading comprehension passages are taken from general English teaching material for non-English department students.

\section{Data Analysis}

In analyzing data collected, the researcher used quantitative data analysis so that the data were analyzed by using statistical techniques. The analysis is used to find the significant difference in the students' reading comprehension ability before and after the use of cloze test. In this research, the researcher used paired sample t-test by SPSS 17.0 to analyze the data.

\section{RESEARCH FINDINGS AND DISCUSSION Research Findings}

This section described the result of students' reading comprehension before and after giving a treatment by testing them using cloze test. Data analysis was done to know the different scores before doing the test and after doing the test. The researcher used a statistical test using Paired Samples t-test analyzed by SPSS 17.0 to ensure the effect of cloze test in testing students' reading comprehension. The analysis result of students' ability on reading comprehension before and after giving a treatment by cloze test can be seen in table 1 . 
Table 1

Frequency Statistic

\begin{tabular}{|c|c|c|c|}
\hline & & PRE-TEST & POST-TEST \\
\hline & Valid & 44 & 44 \\
\hline & Missing & 0 & 0 \\
\hline \multicolumn{2}{|c|}{ Mean } & 46.89 & 65.61 \\
\hline \multicolumn{2}{|c|}{ Median } & 47.00 & 67.00 \\
\hline \multicolumn{2}{|c|}{ Mode } & 47 & 75 \\
\hline \multicolumn{2}{|c|}{ Std. Deviation } & 6.277 & 10.861 \\
\hline
\end{tabular}

Based on table 1 showed that the number of samples in each group was 44 students. The mean score of the pre-test was 46.89 and the mean score of the post-test was 65.61 . The median score for the pre-test was 47.00 and the median score for the post-test was 67.00. Mode score or value which has the highest frequency in the pre-test was 47 however mode score in the post-test was 75. The standard deviation of the pre-test was 6.277 while the standard deviation of the post-test was 10.861. Table 2 is the table of achievement levels by David P Harris (1979).

Table 2

The Achievement Level

\begin{tabular}{|c|c|}
\hline Test Scores & Classification \\
\hline $80-100$ & Good to Excellent \\
\hline $60-79$ & Average to Good \\
\hline $50-59$ & Poor to Average \\
\hline $0-49$ & Poor \\
\hline
\end{tabular}

Both of the mean scores are then classified into the achievement level classification so that students' score on pre-test is classified as poor however students' score on post-test is classified average to good.

Table 3

Frequency of Pre-test

\begin{tabular}{|rr|r|r|r|r|}
\hline & Frequency & Percent & Valid Percent & \multicolumn{2}{|c|}{$\begin{array}{c}\text { Cumulative } \\
\text { Percent }\end{array}$} \\
\hline Valid & 35 & 1 & 2.3 & 2.3 & 2.3 \\
& 37 & 4 & 9.1 & 9.1 & 11.4 \\
40 & 2 & 4.5 & 4.5 & 15.9 \\
42 & 6 & 13.6 & 13.6 & 29.5 \\
45 & 7 & 15.9 & 15.9 & 45.5 \\
47 & 8 & 18.2 & 18.2 & 63.6 \\
50 & 5 & 11.4 & 11.4 & 75.0 \\
52 & 4 & 9.1 & 9.1 & 84.1 \\
55 & 3 & 6.8 & 6.8 & 90.9 \\
57 & 2 & 4.5 & 4.5 & 95.5 \\
60 & 2 & 4.5 & 4.5 & 100.0 \\
Total & 44 & 100.0 & 100.0 & \\
\hline
\end{tabular}


In table 3 showed that the lowest score in the pre-test was 35 and there was one student who got the score $(2.3 \%)$, however, the highest score in the pre-test was 60 and there were two students who got the score $(4.5 \%)$.

Table 4

Frequency of Post-test

\begin{tabular}{|ll|r|r|r|r|}
\hline & Frequency & \multicolumn{1}{|c|}{ Percent } & Valid Percent & Cumulative \\
\hline & & 1 & 2.3 & 2.3 & 2.3 \\
& Vercent \\
\hline & 2 & 4.5 & 4.5 & 6.8 \\
& 45 & 2 & 4.5 & 4.5 & 11.4 \\
55 & 7 & 15.9 & 15.9 & 27.3 \\
60 & 3 & 6.8 & 6.8 & 34.1 \\
62 & 1 & 2.3 & 2.3 & 36.4 \\
65 & 3 & 6.8 & 6.8 & 43.2 \\
67 & 4 & 9.1 & 9.1 & 52.3 \\
70 & 2 & 4.5 & 4.5 & 56.8 \\
72 & 4 & 9.1 & 9.1 & 65.9 \\
75 & 8 & 18.2 & 18.2 & 84.1 \\
77 & 5 & 11.4 & 11.4 & 95.5 \\
80 & 2 & 4.5 & 4.5 & 100.0 \\
Total & 44 & 100.0 & 100.0 & \\
\hline
\end{tabular}

In table 4 showed that the lowest score in the post-test was 40 and there was one student who got the score $(2.3 \%)$, however, the highest score in the post-test was 80 and there were two students who got the score $(4.5 \%)$.

Table 5

Paired Samples Statistics

\begin{tabular}{|ll|r|r|r|r|}
\hline & \multicolumn{1}{|c|}{ Mean } & N & \multicolumn{1}{c|}{ Std. Deviation } & \multicolumn{1}{c|}{ Std. Error Mean } \\
\hline Pair 1 & Pre-test & 46.89 & 44 & 6.277 & .946 \\
& Post-test & 65.61 & 44 & 10.861 & 1.637 \\
\hline
\end{tabular}

Based on the summary of the result of descriptive statistics in table 5 from both samples pre-test and post-test showed that the mean score of the pre-test was 46.89 while the mean score of the post-test was 65.61. The number of samples in the research was 44 non-English department. The standard deviation score of the pre-test was 6.277 and the standard deviation score of the post-test was 10.861. students. The standard error of the mean score of the pretest was 0.946 and the standard error mean score of the post-test was 1.637. The mean score of pre-test 46.86 smaller than 65.61 mean score of post-test, meant that there was a difference mean score of students' reading comprehension between pre-test and post-test.

Table 6

Paired Samples Correlations

\begin{tabular}{|ll|r|r|r|}
\hline & N & Correlation & \multicolumn{1}{c|}{ Sig. } \\
\hline Pair 1 & Pre-test \& Post-test & 44 & .635 & .000 \\
\hline
\end{tabular}

Based on the analysis result on Paired Sample Correlation in table 6, showed correlation coefficient value was 0.635 with a significant value in the amount of 0.000 . Therefore, value of Sig. <alpha $(0.000<0.05)$ meant there was a correlation between variable pre-test and post-test. 
Table 7

Paired Samples Test

\begin{tabular}{|c|c|c|c|c|c|c|c|c|}
\hline & \multicolumn{5}{|c|}{ Paired Differences } & \multirow[b]{3}{*}{$\mathrm{t}$} & \multirow[b]{3}{*}{ df } & \multirow{3}{*}{$\begin{array}{l}\text { Sig. (2- } \\
\text { tailed) }\end{array}$} \\
\hline & \multirow[b]{2}{*}{ Mean } & \multirow{2}{*}{$\begin{array}{c}\text { Std. } \\
\text { Deviation }\end{array}$} & \multirow{2}{*}{$\begin{array}{l}\text { Std. } \\
\text { Error } \\
\text { Mean }\end{array}$} & \multicolumn{2}{|c|}{$\begin{array}{l}\text { 95\% Confidence } \\
\text { Interval of the } \\
\text { Difference }\end{array}$} & & & \\
\hline & & & & Lower & Upper & & & \\
\hline $\begin{array}{ll}\text { Pair } & \text { Pre-test - } \\
1 & \text { Post-test }\end{array}$ & -18.727 & 8.412 & 1.268 & -21.285 & -16.170 & -14.767 & 43 & .000 \\
\hline
\end{tabular}

Based on table 7, it showed the significance value Sig. (2-tailed) < alpha $(0.000<0.05)$, therefore cloze test is an appropriate test to improve students' ability on reading comprehension. It meant that there was an effect of cloze test on improving non-English department students' reading comprehension.

\section{Discussion}

Jack and Willy (2002) stated cloze test is one of the reading assessments that help students to explore the organization and many vocabularies of a text. The theory is in accordance with the findings of this research. The students not only read the reading text but also produce a word to fit a given context. The cloze test requires a search of a distribution of elements for missing elements and students use a whole variety of cues to predict what is next in a sentence. Then cloze helps students to recognize the interrelationships of language and to develop an awareness of sequence. It impacts those students have to know the appropriate meaning of missing words to make the right sentence in a reading text.

This research aimed to answer the following research problems: 1) What is the result of the non-English department students' reading comprehension tested by using cloze test? 2) Is there any effect of using cloze test on non-English department students' achievement on reading comprehension? Based on the data analysis, the student's score in pre-test data showed that the lowest score is 35 , the highest score is 60 , the mean score is 46.89 . The students' score in post-test data showed that the lowest score is 40 , the highest score is 80 and the mean score is 65.61. According to achievement level classification by Harris (1979) mean score of 46.89 in pre-test data is classified as poor, however, in post-test students' achievement score of 65.61 is classified average to good. Ultimately, based on the data analysis, the researcher found that there was an improvement in students' achievement in comprehending the reading passage. It could be proven by comparing the mean score of the pre-test and the mean score of the post-test. This finding showed there was a different score before and after giving treatment. With regard to the score, it was indicated the result of the non-English department students' reading comprehension tested by using cloze test is good. The student's performance in the post-test is better than the pre-test indicated that the use of cloze test affects non-English department students' achievement on reading comprehension.

The result of paired samples t-test analysis showed the significance value Sig. (2-tailed) $<$ alpha $(0.000<0.05)$. Therefore, the alternative hypotheses which stated that there is an effect of using cloze test on improving non-English department students' reading comprehension is accepted.

The researcher found that cloze test can help the non-English department students comprehend reading passages easily because they are interested in learning to find out the information from the reading text. The students can determine the words to fill in after they know the context. They can choose the word (s) to fill in the text that familiar to them. The weakness of this research is reading passages used in this research is familiar to the students since reading passages used in this research are teaching material related to their departments. 


\section{CONCLUSION}

Based on the research findings, the researcher draws some conclusions as follows: 1) The result of students' achievement on reading comprehension tested by cloze test is 65.61 . 2) According to the criteria used to determine achievement level, this result is categorized as average to good. 3) The analysis result showed the significance value Sig. (2-tailed) < alpha $(0.000<0.05)$, therefore there was an effect of using cloze test on improving non-English department students' reading comprehension.

\section{REFERENCES}

Brown, H. D. (2000). Principle of Language Learning and Teaching. New Jersey: Prentice Hall, Inc.

Brown, H. D. (2004). Language Assessment: Principles and Classroom Practices. White Plains, NY: Pearson Education.

Creswell, J. W. (2014). Research design, qualitative, quantitative, and mixed methods approach (4th Ed.). United States of America: Sage Publications.

Duke, N. (2003, March 7). Comprehension instruction for informational text. Presentation at the annual meeting of the Michigan Reading Association, Grand Rapids, MI.

Ema, E. T. (2019). Effectiveness of test design between of cloze test and multiple choice test for reading comprehension. Jurnal Ellite (Journal of Education, Linguistics, Literature and Language Teaching), 2(02), 53-68. https://ejurnalunsam.id/index.php/ELLITE/article/view/1782.

Eskey, D. E. (2005). Reading in a second language. In E. Hinkel (Eds.), Handbook of research in second language teaching and learning. Mahwah, NJ: Lawrence Erlbaum.

Febriyanti, P. (2017). The correlation between reading comprehension and students' ability in answering cloze test of the seventh grade students at SMPN I Kalipuro Banyuwangi in the 2014/2015 Academic Year. Language and Art Journal, 1(2), 36-47. https://doi.org/10.36526/ln.v1i02.463.

Harmer, J. (2002). The Practice of English Language Teaching (3rd Ed.). England: Longman.

Harris, D. P. (1979). Testing English as A Second Language. New York: Tata McGraw-Hill Company.

Heaton, J. B. (1998). Writing English Language Tests. New York: Longman.

Issac, S., \& Michael, W. B. (1981). Handbook in Research and Evaluation. California: Edits Publisher.

Jack, C. R., \& Willy, A. R. (2002). Methodology in Language Teaching an Anthology of Current Practice. New York: Cambridge University Press.

Kintsch, W. (1998). Comprehension: A Paradigm of Cognition. Cambridge, UK. Cambridge: University Press.

Lu, G. (2006). Cloze Test and Reading Strategies in English Language Teaching in China [Unpublished Master Thesis]. The Faculty of Education: University of Western Cape.

McNamara, D. S., \& Magliano, J. P. (2009). Towards a comprehensive model of comprehension. In B. Rose (Eds.), The psychology of learning and motivation (pp. 297-384). New York: NY: Academic Press.

Oller, J. W., \& Jonz, J. (1994). Why Cloze Procedure? London: Associated University Press.

Oller, J. W, Jr. (2006). Close Tests of the second language proficiency and what they measure. Language Learning 23(1). 105-118. https://doi.org/10.1111/j.14671770.1973.tb00100.x

Olson, J. P., \& Diller, M. H. (1982). Learning to teach reading in elementary school. London: Macmillan Publishing Company. 
RAND Reading Study Group. (2002). Reading for under-standing: toward a research and development program in reading comprehension. Santa Monica, CA: Office of Education Research and Improvement

Richards, J. C., \& Schmidt, R. (2002). Dictionary of language teaching and applied linguistic $\left(3^{\text {rd }}\right.$ Ed.). Malaysia: Pearson Education Limited

Wahdaniah, Marbun, R., \& Husin, S. (2013). The use of cloze test in increasing the students' reading comprehension. Jurnal Pendidikan dan Pembelajaran Khatulistiwa, 2(1) https://jurnal.untan.ac.id/index.php/jpdpb/article/view/495/pdf. 